\title{
Valuing an entrepreneurial enterprise
}

By: David B. Audretsch and Albert N. Link

Audretsch, D.B., Link, A.N. Valuing an entrepreneurial enterprise. Small Business

Economics 38, 139-145 (2012). https://doi.org/10.1007/s11187-011-9409-5

This version of the article has been accepted for publication, after peer review (when applicable) and is subject to Springer Nature's AM terms of use, but is not the Version of Record and does not reflect post-acceptance improvements, or any corrections. The Version of Record is available online at: $h$ ttp://dx.doi.org/10.1007/s11187-011-9409-5

\begin{abstract}
:
This article focuses on valuation issues and methods that are related to a closely held entrepreneurial enterprise. This focus is motivated by the fact that the number of small, closely held business start-ups, which we refer to broadly by the term "entrepreneurial enterprises," continues to grow year on year, and new business ventures remain the primary source for employment growth in the USA and most industrialized nations. Also, the topic of valuation of entrepreneurial enterprises has for the most part been ignored. The traditional approaches to valuation of small, closely held entrepreneurial enterprises are, in our view, wanting in a number of important respects. Simply, traditional valuation methods are modeled in a manner that is applicable to a going-concern business with a history of sales and revenues. That is not the case for an entrepreneurial enterprise as we define it, and thus use of traditional valuation methods is questionable.
\end{abstract}

Keywords: entrepreneurship | valuation | closely held business

\section{Article:}

\section{Introduction}

What makes an individual an entrepreneur, and what makes his or her commercial endeavors an entrepreneurial enterprise? These two questions, especially the former, have occupied the minds of many scholars and practitioners for centuries; the answers to each are as varied as those who have given thought to these questions. Envisioning an entrepreneur even occupied the canvas of Maestro Salvador Dalí, arguably an entrepreneur in his own right. However, we suspect that few self-proclaimed entrepreneurs would envision themselves as Dalí envisioned "The Entrepreneur."

We do not attempt to offer a precise construct or definition of either an entrepreneur or an entrepreneurial enterprise in this paper. In fact, others have already trodden that ground. ${ }^{1}$ Rather, we only offer, as introduction to the valuation theme of this paper, salient characteristics of an entrepreneur and an entrepreneurial enterprise. The primary emphasis in this article is on

\footnotetext{
${ }^{1}$ Hébert and Link $(1988,2009)$ have provided what is arguably the definitive historical trace of who the entrepreneur is and what he or she does.
} 
valuation, that is, on how one thinks about how to determine the fair market value of an entrepreneurial enterprise, a closely held entrepreneurial enterprise in particular. ${ }^{2,3}$

There are two reasons that we focus on valuation issues and methods that are related to a closely held entrepreneurial enterprise. The first reason is that the number of small, closely held business start-ups, which we refer to broadly by the term "entrepreneurial enterprises," continues to grow year on year, and new business ventures remain the primary source for employment growth in the USA and most industrialized nations. Second, the topic of valuation of entrepreneurial enterprises has for the most part been ignored. Traditional approaches to the valuation of small, closely held entrepreneurial enterprises are, in our view, wanting in a number of important respects. Simply, traditional valuation methods are modeled in a manner that is applicable to a going-concern business with a history of sales and revenues. That is not the case for an entrepreneurial enterprise as we define it, and thus use of traditional valuation methods is questionable.

Our valuation methodology is simple. When valuing an entrepreneurial enterprise - a technology-based entrepreneurial enterprise in particular - the key to approaching the valuation is to focus on and understand the availability of alternative or complementary technologies rather than the existence of substitutable products.

\section{Defining an entrepreneur}

Before defining an entrepreneur for valuation purposes, we turn to the intellectual history of thought about such a person. ${ }^{4}$ We first reflect selectively on Joseph Schumpeter's view of an entrepreneur as an innovator; Schumpeter viewed entrepreneurial activity within the context of a theory of economic development. According to Schumpeter:

[E]veryone is an entrepreneur only when he actually "carries out new combinations [of resources]," and loses that character as soon as he has built up his business, when he settles down to running it as other people run their businesses. (1934, p. 78)

To continue, implementing new ideas and discovering new combinations of resources define an entrepreneur as a disequilibrating agent of change; the purposeful environment in which this occurs is an entrepreneurial enterprise. Thus, it is clear that the entrepreneur in Schumpeter's domain is the key agent of economic growth and development. Schumpeter (1934, p. 74) was quite emphatic about this role of the entrepreneur when he wrote, "The carrying out of new

\footnotetext{
2 This article draws directly, with permission, from Audretsch and Link (2012).

${ }^{3}$ A closely held business is one for which the ownership is held by one or more individuals. There is no publicly traded stock.

${ }^{4}$ Hébert and Link (2009) write that the historical literature in economics offers at least a dozen somewhat overlapping characterizations of who the entrepreneur is and what he or she does. These characterizations of an entrepreneur include: the person who assumes the risk associated with uncertainty, the person who supplies financial capital, an innovator, a decision-maker, an industrial leader, a manager or superintendent, an organizer and coordinator of resources, the owner of an enterprise, an employer of factors of production, a contractor, an arbitrageur, and an allocator of resources among alternative uses.
} 
combinations we call 'enterprise'; the individual whose function it is to carry them out we call "entrepreneurs." 5

With this Schumpeterian view of the entrepreneur in mind, we also reflect on the thoughts of Nobel Laureate T. W. Schultz (1975). He defined entrepreneurship simply as the ability to deal with disequilibria. ${ }^{6}$ Thus, Schultz widened Schumpeter's concept of entrepreneurship to include any economic agent who has this ability. Schultz insisted that the supply of such entrepreneurial talent is a scarce economic resource. This view logically raises the question: if such talent is scarce, where does one acquire the ability to deal with disequilibria?

Fritz Machlup, who reflected on the general writings of earlier scholars and on the implications of Schultz's definition of an entrepreneur, answered this question, at least in part. Machlup argued that formal education, which is largely based on codified knowledge, is not the only source of knowledge upon which an entrepreneur might draw. Rather, knowledge is also gained experientially, and experiential education is often based on tacit knowledge. Individuals can acquire knowledge from their day-to-day experiences, which "will normally induce reflection, interpretation, discoveries, and generalizations" (Machlup 1980, p. 179). Moreover, the cost of acquiring experiential knowledge and knowing that it has in fact been acquired is related to differential abilities, some of which may be learned but others of which are likely instinctive:

Some alert and quick-minded persons, by keeping their eyes and ears open for new facts and theories, discoveries and opportunities, perceive what normal people of lesser alertness and perceptiveness would fail to notice. Hence new knowledge is available at little or no cost to those who are on the lookout, full of curiosity, and bright enough not to miss their chances. (Machlup 1980, p. 179)

We suggest that Machlup's view offers some initial insight into the question about where one acquires the ability to deal with disequilibria. One acquires - likely over time - an ability to deal with disequilibria by continuing to be perceptive, that is, by continuing to be on the lookout, by continuing to be full of curiosity, and by continuing to be bright enough not to miss opportunities.

Here, we view an entrepreneur and his or her enterprise very broadly. An entrepreneur is one who perceives an opportunity and has the ability to act on that opportunity. For the purpose at hand, it does not matter whether the entrepreneur provoked the change that created the

\footnotetext{
${ }^{5}$ According to Hébert and Link (2009), Schumpeter's entrepreneur was the motivating force of economic change. The talented few who carry out innovations by devising new technologies, discovering new products, and developing new markets account for the short and long cycles of economic life. Schumpeter saw economic development as a dynamic process, a disturbance of the status quo. He viewed economic development not as a mere adjunct to the central body of orthodox economic theory, but as the basis for reinterpreting a vital process that had been crowded out of mainstream economic analysis by the static, general equilibrium approach. The entrepreneur is a key figure for Schumpeter because he is, quite simply, the persona causa of economic development, and economic development occurs in industrial and commercial life by carrying out of new combinations in production. It is accomplished by an entrepreneur who is first foremost an innovator.

${ }^{6}$ Whereas Schumpeter's entrepreneur brought about disequilibrium, Schultz's entrepreneur is an economic agent who has the ability to deal with that disequilibrium.
} 
opportunity or simply perceived that it existed. ${ }^{7}$ Either way, action implies that the entrepreneur has the courage to embrace risk in the face of uncertainty; thus, an entrepreneurial enterprise, be it physical or virtual, is the manifestation of the entrepreneur's perception and action.

\section{Valuing an entrepreneurial enterprise}

The valuation literature is replete with approaches to valuing a going-concern businesstechnology based or otherwise - that has a well-documented history of sales or revenues. Such is the state of the art in the practice of valuation regardless of the background of the person conducting it. Unfortunately, that state of the art is not applicable - some might say not even remotely applicable - to the current and growing population of technology-based entrepreneurial enterprises in need of valuation.

Of course, many professional and certified valuators and self-identified practitioners have for the most part skirted this important issue by simply assuming the problem away through legerdemain. For example, some are content simply to say that the valuation of an entrepreneurial enterprise is tricky and leave it at that. ${ }^{8}$

Those who have not skirted the issue have approached it incorrectly, we believe. We have often heard from professional and certified valuators, and even more frequently read in treatises and textbooks, that traditional evaluation approaches are directly applicable to any entrepreneurial undertaking. All one must do, such valuation pundits often say, is assume the to-be-valued business's revenue history can be approximated by that of a comparable company, where the term comparable refers to a company selling a substitute product.

If one buys into this argument, the substitute product becomes the yardstick by which to measure the expected future market success, and hence the market value, of the entrepreneurial enterprise. However, does such a yardstick even exist? In our opinion, it does not, and those who advocate the view that one does are at best naïve and at worst rather cavalier. More importantly, those who hold such a view are apparently oblivious to the reality that theirs is a view based on internally inconsistent facts. First, as we have previously stated, if the enterprise is truly entrepreneurial, by definition there would be no other comparable company in terms of either selling or developing a substitutable or similar product.

Second, if there were in fact another company that was producing a substitute or similar product, the to-be-valued enterprise in question would not truly be entrepreneurial. Assuming that this to-

\footnotetext{
${ }^{7}$ Hébert and Link (2009, p. 105) address this distinction by posing the following question: "Does it matter whether the entrepreneur is the person who provokes change or merely [the person who] adjusts to it? If we rely on the most elemental features of entrepreneurship - perception, courage [to take on risk], and action - the answer is probably not. Entrepreneurial action means creation of opportunity as well as response to existing circumstances."

${ }^{8}$ In our opinion, Nollsch (2010) correctly states that "Valuation is a tricky subject for early-stage entrepreneurs raising capital. With a limited performance history of the business, how do you accurately determine valuation?" He also states, "The best thing an entrepreneur can do to increase their chances of funding and improve their valuation is to focus on lowering the risk profile [being] executed on the business plan.... Ultimately, valuation for early stage companies is a negotiation exercise and requires a bit of haggling back and forth." We disagree that the best thing an entrepreneur can do is focus on lowering the risk profile of his or her enterprise, and we argue that it is possible-for a technology-based enterprise in particular - to conduct a systematic valuation using traditional valuation tools.
} 
be-valued enterprise was attempting to enter a market in which there was another similar company, the existing company's revenue history or market penetration might still be irrelevant for fair market valuation of the entrepreneurial enterprise because the growth path of the existing company occurred in a market environment that lacked competition. Vying for market share leads to a number of rivalrous behaviors, including advertising, price competition, and quality competition.

Third, even if a historically operating technology-based company could be identified, it would be neither relevant to the current economic environment nor representative of the to-be-valued business because it, unlike the to-be-valued business, has a history of being successful in the marketplace. One does not know and should not assume that the entrepreneurial enterprise will be successful over time. ${ }^{9}$

Tables 1, 2, 3, and 4 briefly outline four traditional approaches or methods for valuation of a going concern: the present value of adjusted future net earnings valuation method, the price-toearnings ratio valuation method, the adjusted net asset valuation method, and the capitalization of excess earnings valuation method (Audretsch and Link 2012). While these tables are cryptic in their explanation of the steps involved in executing each method, our comments about the applicability of each clearly point out the limitations of each and thus the need to rethink how to value an entrepreneurial enterprise.

Table 1. Present value of adjusted future net earnings valuation method

\begin{tabular}{|c|c|c|}
\hline Step & Procedure & Comments about applicability for an entrepreneurial enterprise \\
\hline 1 & $\begin{array}{l}\text { Determine the expected life of } \\
\text { the business - a limited life } \\
\text { of } n \text { years or an indefinite life }\end{array}$ & $\begin{array}{l}\text { Given the nature of an entrepreneurial enterprise and its entrepreneur, it is } \\
\text { impossible to determine the life of the enterprise. To do so would be, to } \\
\text { paraphrase Machlup, to anticipate when the next alert and quick-minded } \\
\text { person would, by keeping his or her eyes and ears open for new facts and } \\
\text { theories, discoveries, and opportunities, perceive a new opportunity }\end{array}$ \\
\hline 2 & $\begin{array}{l}\text { Estimate an appropriate } \\
\text { discount rate, } r\end{array}$ & $\begin{array}{l}\text { Because the discount rate reflects the resource and market risk of the } \\
\text { enterprise, and because there are no comparables, } r \text { cannot be estimated }\end{array}$ \\
\hline 3 & $\begin{array}{l}\text { Normalize the income } \\
\text { statement }\end{array}$ & $\begin{array}{l}\text { By definition, there are no revenues on the enterprises' income statement. } \\
\text { Normalizing it for, say, owner's compensation could be done, but it would } \\
\text { have no useful value }\end{array}$ \\
\hline 4 & $\begin{array}{l}\text { Calculate a weighted average } \\
\text { of adjusted future net earnings } \\
\text { assuming that a weighted } \\
\text { average of adjusted future net } \\
\text { earnings is appropriate }\end{array}$ & There are no net earnings to weight \\
\hline 5 & $\begin{array}{l}\text { Calculate the present value of } \\
\text { the weighted average of } \\
\text { adjusted future net earnings }\end{array}$ & Absent net earnings, no present value can be calculated \\
\hline 6 & $\begin{array}{l}\text { Adjust for marketability as } \\
\text { appropriate }\end{array}$ & $\begin{array}{l}\text { Absent a present value estimate, a marketability adjustment is not } \\
\text { meaningful }\end{array}$ \\
\hline
\end{tabular}

\footnotetext{
${ }^{9}$ Acs and Mueller (2008) present empirical information that suggests that the average effective life of an entrepreneurial start-up is short, perhaps not longer than 5 years.
} 
Table 2. Price-to-earnings ratio valuation method

\begin{tabular}{|lll|}
\hline Step & Procedure & Comments about applicability for an entrepreneurial enterprise \\
\hline 1 & $\begin{array}{l}\text { Identify a publicly traded company or } \\
\text { set of publicly traded companies and } \\
\text { calculate a price-to-earnings ratio }\end{array}$ & $\begin{array}{l}\text { By definition of an entrepreneurial enterprise, there are no publicly } \\
\text { traded companies that are comparable }\end{array}$ \\
2 & $\begin{array}{l}\text { Normalize the income statement to } \\
\text { determine adjusted future net earnings }\end{array}$ & $\begin{array}{l}\text { By definition, there are no revenues on the enterprise's income } \\
\text { statement. Normalizing it for, say, owner's compensation could be } \\
\text { done, but it would have no useful value } \\
3\end{array}$ \\
$\begin{array}{l}\text { Multiply the above two values, and } \\
\text { Then adjust the product by a publicly a moot step absent the above information } \\
\text { traded marketability discount } \\
\text { Adjust by an ownership premium }\end{array}$ & This too is a moot step \\
\hline
\end{tabular}

Table 3. Adjusted net asset valuation method

\begin{tabular}{|c|c|c|}
\hline Step & Procedure & Comments about applicability for an entrepreneurial enterprise \\
\hline 1 & $\begin{array}{l}\text { Adjust the balance sheet to } \\
\text { reflect the fair market value of } \\
\text { assets }\end{array}$ & $\begin{array}{l}\text { An entrepreneurial enterprise will have a balance sheet even in the absence of } \\
\text { revenues, and whatever assets it has will have a market value. However, the } \\
\text { relevant assets of the enterprise are cognitive or intangible; that is, they are } \\
\text { the vision of the entrepreneur and that will not show up on the balance sheet }\end{array}$ \\
\hline 2 & $\begin{array}{l}\text { Determine the value of } \\
\text { goodwill, if any }\end{array}$ & $\begin{array}{l}\text { There is no quantifiable or marketable goodwill in an entrepreneurial } \\
\text { enterprise }\end{array}$ \\
\hline 3 & $\begin{array}{l}\text { Subtract total liabilities from } \\
\text { adjusted total assets to arrive } \\
\text { at adjusted net assets }\end{array}$ & $\begin{array}{l}\text { Net assets can be calculated, but for the reasons stated in step 1, net assets } \\
\text { from the balance sheet will understate the true asset value of the enterprise }\end{array}$ \\
\hline 4 & $\begin{array}{l}\text { Adjust for transfer } \\
\text { marketability as appropriate }\end{array}$ & $\begin{array}{l}\text { It would be guesswork, we think, to estimate if there is a buyer, much less } \\
\text { when he or she might come forward }\end{array}$ \\
\hline
\end{tabular}

Table 4. Capitalization of excess earnings valuation method

\begin{tabular}{|c|c|c|}
\hline Step & Procedure & $\begin{array}{l}\text { Comments about applicability for an } \\
\text { entrepreneurial enterprise }\end{array}$ \\
\hline 1 & $\begin{array}{l}\text { Calculate a weighted average of adjusted future net } \\
\text { earnings from the income statement }\end{array}$ & $\begin{array}{l}\text { There are no adjusted future net earnings to } \\
\text { weight }\end{array}$ \\
\hline 2 & $\begin{array}{l}\text { Calculate a weighted average of the market value of } \\
\text { tangible assets from the balance sheet }\end{array}$ & $\begin{array}{l}\text { This step can be done with adjustments to the } \\
\text { balance sheet }\end{array}$ \\
\hline 3 & $\begin{array}{l}\text { Determine an expected return on the weighted average of } \\
\text { the market value of tangible assets }\end{array}$ & $\begin{array}{l}\text { A risk-free market rate of return could be } \\
\text { determined }\end{array}$ \\
\hline 4 & $\begin{array}{l}\text { Subtract the return expected on these tangible assets from } \\
\text { the weighted average of adjusted future net earnings to } \\
\text { determine excess earnings }\end{array}$ & $\begin{array}{l}\text { This step cannot be done because there are no } \\
\text { adjusted future net earnings. }\end{array}$ \\
\hline 5 & Capitalize excess earnings & $\begin{array}{l}\text { Because there are no excess earnings, there is no } \\
\text { value to capitalize }\end{array}$ \\
\hline 6 & $\begin{array}{l}\text { Add to the capitalized value of excess earnings the fair } \\
\text { market value of current tangible assets and adjust the sum } \\
\text { for ownership control and marketability }\end{array}$ & $\begin{array}{l}\text { This step cannot be done because of missing } \\
\text { information }\end{array}$ \\
\hline
\end{tabular}

\section{The need for a valuation methodology}

We argue that one should approach the valuation of a technology-based entrepreneurial enterprise through an understanding of the role of alternative or complementary technologies. In 
most instances, any innovation that an entrepreneur is trying to develop from a new or burgeoning technology will only penetrate the market once attendant technologies are in place. Thus, forecasting alternative or complementary technologies, and their market impact, is the key to valuing an entrepreneurial enterprise (Audretsch and Link 2012).

The need for a systematic methodology is, we believe, great and growing. Below we offer some generalized statistics that address the breadth of the landscape to which our methodology might apply. These statistics motivate the question: How many new technology-based entrepreneurial ventures are in need of valuation each year? Our approach to answering the question of how many new technology-based entrepreneurial ventures are in need of valuation each year begins with selected information specific to the USA. However, we will extrapolate our findings to the rest of the world. The US Small Business Administration Office of Advocacy reported that, in 2007 , there were nearly 670,000 small business births in the country, where "small business" refers to a company with beginning year employment of less than $500 .{ }^{10}$ Of those 670,000 small business births, about 640,000 had beginning year employment of less than $20 .^{11}$

The number of small business births in the USA has increased steadily for nearly two decades, even with the intermittent and expected dips during recessionary times; for example, the Small Business Administration Office of Advocacy (2010) estimated that US small business births in 2009 , near the trough of the current business cycle, were just over 550,000. Even if these burgeoning enterprises are short lived, all are likely to need valuation at some point in time for seeking venture capital, borrowing funds from third parties, or being sold. ${ }^{12}$ However, our focus here is delimited; we are addressing only technology-based enterprises.

Using 600,000 as a conservative illustrative steady-state number of total new business births per year in the USA, at least 12\% will be technology based. Reynolds and Curtin (2008, p. 214) estimated from their analysis of the panel study of entrepreneurial dynamics that, on average, $12 \%$ of start-ups "initiated patent, copyright, or trademark protection." Thus, we offer here 72,000 (i.e., $12 \%$ of 600,000 ) as a lower-bound point estimate of the steady-state number of new technology-based enterprises in the USA that will potentially need to be valued each and every year.

To substantiate the lower-bound nature of this number of 72,000 - aside from the conservative base of 600,000 from which it came - note that it does not take into account valuation issues related to spin-off divisions of companies established under the umbrella of the parent company that is pursuing a new technology-based product. To our knowledge, there are no estimates for this umbrella effect, but if popular press accounts are a barometer, the number of new

\footnotetext{
${ }^{10}$ There are births and deaths of small businesses every year. In 2009, the turnover rate (i.e., total deaths divided by total births) in the USA was 0.90 (US Small Business Administration 2009). This statistic does not imply that $90 \%$ of all small businesses that started in 2009 also died that same year. Rather, the total number of small firms started in previous years that died in 2009 was $90 \%$ of the total of small firms that were started in 2009 . Even dying firms might be in need of valuation, if for no other reason than to determine a fair market liquidation value.

${ }^{11}$ See http://www.sba.gov/advo/research/dyn_us_tot.pdf.

12 Regarding the population of small businesses in the USA, the following statistics emphasize the number of smallsized firms with fewer than 20 employees in operation. In total, 89.4\% of the over 6 million firms in the USA in 2007 had fewer than 20 employees (US Census Bureau 2007).
} 
technology-based enterprises in the USA that will potentially need to be valued each year may be much greater than our conservative estimate of 72,000 .

Globally, the annual number of entrepreneurial enterprises in need of valuation is much larger. Mason, for example, suggested that "with 472 million entrepreneurs worldwide attempting to start 305 million companies, approximately 100 million new businesses (or one third) will open each year around the world" (2010, p. 3). Also, if 12\% of these 100 million new businesses are technology based, the potential applicability of the methodology we offer herein is vast.

\section{References}

Acs, Z. J., \& Mueller, P. (2008). Employment effects and business dynamics: Mice, gazelles and elephants. Small Business Economics, 30, 85-100.

Audretsch, D. B., \& Link, A. N. (2012). Valuing an entrepreneurial enterprise. New York: Oxford University Press.

Hébert, R. F., \& Link, A. N. (1988). The entrepreneur: Mainstream views and radical critiques. New York: Praeger.

Hébert, R. F., \& Link, A. N. (2009). A history of entrepreneurship. London: Routledge.

Machlup, F. (1980). Knowledge and knowledge production. Princeton, NJ: Princeton University Press.

Mason, M. K. (2010). Worldwide business startups. www.moyak.com/papers/business-startupsentreprneurs.html. Accessed 20 Sept 2011.

Nollsch, J. (2010). Valuation is a tricky subject for early-stage entrepreneurs raising capital. http://angelcapitalsummit.org/blog/valuation-tricky-subject-for-early-stageentrepreneurs-raising-capital. Accessed 3 Sept 2011.

Reynolds, P. D., \& Curtin, R. T. (2008). Business creation in the United States: Panel study of entrepreneurial dynamics II initial assessment. Foundation and Trends in Entrepreneurship, 4, 155-307.

Schultz, T. W. (1975). The value of the ability to deal with disequilibria. Journal of Economic Literature, 13, 827-846.

Schumpeter, J. A. (1934). The theory of economic development. Cambridge: Harvard University Press.

US Census Bureau. (2007). 2007 Economic Census. Washington, DC: Government Printing Office.

US Small Business Administration. (2009). The small business economy: A report to the President. Washington, DC: Government Printing Office.

US Small Business Administration, Office of advocacy. (2010). Frequently asked questions. www.sba.gov/advo. 